\title{
Investigating Ambiguity in Headlines of Contemporary Yorùbá Newspapers
}

\author{
Olútọ́lá ọ̀șunnúgà \\ Olábísí Ọnàbáńjọ University, Nigeria \\ *Corresponding Author:tolaosunnuga@yahoo.co.uk
}

Copyright ( 2013 Horizon Research Publishing All rights reserved.

\begin{abstract}
In this paper, an analysis of form of linguistic ambiguity in the headlines of contemporary Yorùbá newspapers is presented. The paper analyses 100 verbally ambiguous headlines in some newspapers. The focus of the paper is on examples of lexical and structural ambiguity that result in involuntary humour. This is usually contrived by Yorùbá newspaper wr iter for the sake of entertainment which makes the headlines funny . Therefore, this paper examined some words and expression which are possibly ambiguous in the headlines of contemporary Yorùbà newspapers. The headlines collected in our corpus and analysed were selected precisely because the sources of ambiguity that produced the humorous effect were of a linguistic nature. This is in an attempt to propose a systematic analysis of humorous headlines that have rarely been considered in the Yorùbá literature.
\end{abstract}

Keywords Linguistic Ambiguity, Figurative Language, Yorùbá Newspapers

\section{Introduction}

A major component in the Yoruba newspaper discourse is the headline, which has become an interest of linguistics and stylistics. This is because newspaper headlines are considered to have their own characteristics and status in news discourse (Bell, 1991). Newspaper headlines are written in a special kind of language with its own vocabulary and grammar. Headlines have a special grammar which differs from that of ordinary sentence . Yorùbá newspaper writing style generally consists of three parts. These are: headlines, lead and body. The headline is the most interesting of them, because its grammar and usage are very characteristic. Fairclough (1995:21) states that "headlines have distinctive syntactic properties, which make them a grammatical oddity. " The headline is a unique type of text. It has a range of functions that specifically dictate its shape, content and structure, and it operates within a range of restrictions that limit the freedom of the writer (Reah , 1998:13-14). It encapsulates the story, i.e. article content, in a minimum number of words, attracts the reader to the story and, if it appears on the front page, attracts the reader to the paper. Because of the function of the headline, and in view of limited space at the disposal of the writer, he makes some linguistic choices which sometimes result in ambiguity.

\section{The Yorùbá Newspapers}

The Yorùbá people are a major ethnic group of South-West Nigeria. They constitute over 50 million people. Beyond the borders of Nigeria, significant population of Yorùbá can be found in Republic of Togo and Siera Leone . There has never been any debate as to which was the first Yorùbá newspaper because several scholars have identified İwé Ìròyìn fún Àwọn ará Ėgbá àti Yorùbá(Newspaper for the Ègbá and Yorùbá) published in 1859 by a missionary turned journalist; Henry Townsend, as the first from which all other newspapers in Nigeria (in English and other Nigerian languages) took their cue. Though it was published fortnightly and later became bilingual in 1860 yet it thrived well because it printed monthly copies of 503 on the average between 1859 and 1870 when its monthly copies rose to 800 . Since its first experience in 1859, Yorùbá newspapers have shaped culture, influence politics, played an important role in business and affected the daily lives of the Yorùbá . Yorùbá newspapers inform the public of important affairs; they provide information on which many readers form opinion. However, the efforts that culminated in the birth of contemporary Yorùbá newspapering st arted in 1980's with the emergence of Àláròyé in 1985.

The research focuses on five popular Yorùbá newspapers in circulation between 1999 and 2012. The newspapers are: Akéde Ágbáyé, Akéde Odùduwà, Ajọrò, Alàròyé and Aláriyá Oòduà. Why 1999? That was a year when democratic government was restored in Nigeria. The emergence of a civilian government guaranteed freedom of press unlike the Military regimes that existed prior to 1999 which censored free press at will. The change in government created a conducive atmosphere for the establishment of many more newspapers in English and other Nigerian languages. On the other hand, 1999 was the year the first Yorùbá man was 
democratically elected and sworn in as the president of Nigeria. For this reason, and taking into cognizance that the elected President - Chief Olú șẹgún Obasanjọ́ - was just released from the prison, an average Yorùbá person wanted to know if he was safe and if he would not be overthrown by the military. The Yorùbá people therefore wanted a medium they could trust, one that was written in their own language where they could have first hand information about the president. The Yorùbá newspaper publishers saw this need and rose to the task by publishing the newspapers. The newspapers come in form of weekly and monthly publications and are both referred to as liwé liròyin lédè Yorùbá; meaning Yorùbá newspapers . Conceptually, newspapers are used in this study to refer to the weekly and monthly types. While the weekly is commonly referred to as İwé Íroyin Yorùbá (Yoruba Newspapers), the monthly is called Magasiìni Yorùbá (Yoruba magazines). However, our study found out that the two types are being generically referred to as İwé Íroyin Yorùbá by the readers and, surprisingly by some of the editors. Besides, we discovered that there is no significant difference between the format of İwé Iròyin and Magasiinì Yorù bá when compared to their English counterparts.

From our study we provisionally concluded that the Yorùbá newspapers pay attention primarily to the following kind of news categories: politics (between federal government and opposition parties), socio-economic situation (especially gap between the rich and the poor) and political activities of State and local governments. Other features of Yorùbá newspapers include : entertainment, sports, crime and advertisement.

\section{Theoretical Framework: Semantics}

For lucid analysis. I adopted semantic theory in the analysis and interpretation of the data. As a branch of Linguistics, semantics is defined as the study of meaning. According to Hurford and Heasley (1983:31), semantic is the study of meaning in language. In semantics, there is need to explain and clarify the nature of meaning even though there is no universal agreement on the nature of meaning or about the way in which meaning should be described. Semantic theory is a part of a larger enterprise, linguistics theory, which includes the study of syntax and phonetics besides the study of meaning. (Hurford and Heasley (1983:11) The preliminary properties of language which all linguists would agree that a semantic theory must explain are (1) the nature of word meaning and sentence meaning - as well as the relations between these, (2) ambiguity as a phenomenon of natural language, (3) relations between sentences of a language - synonymy, entailment, contradiction etc.

\section{Lexical Ambiguity}

According to Leech (1981:30), 'an expression is said to be ambiguous when more than one interpretation can be assigned to it'. Ambiguity can happen in one word, phrase or sentence. Like any other languages , Yorùbá is used as a spoken language and has a written form. Both of them have similarity in their function, which is to convey messages. While they have the same function, there is a difference in the way of delivering the messages. In spoken language, speakers deliver the messages and utter the words directly to the listeners, while writers use some written document to deliver the messages to the readers. Because written language does not deliver the messages directly, readers sometimes get confused in determining the meaning of the sentences and expressions. Besides, written language uses more complex grammar than spoken language. Written language also does not use pauses, hesitations, tone of voices, stress, and intonations. That is why sometimes the sentences in written language can be interpreted and ascribed more than one meaning. When this happens, it is called ambiguity. Lexical ambiguity is conveyed by a word with more than one possible meaning in a context There are many words and phrases in Yorùbá newspapers that are potentially ambiguous such that the readers sometimes get confused in determining the meaning. Let's examine the following headlines where lexical items result in ambiguity.

(1) Alex Akínyẹlé, Afínjú ọkùnrin tó fẹ́ràn nnikan Òyìnbó (Àjọò, 4-10-1999:4)

Alex Akinyele, a nice-looking man who loves white's woman thing.

(2) Ọlọ́kadà mú nnikan fúnyàwó Sẹnétọ̀ ni Sẹ́nétọ bá ń bínú (Akéde Àgbáyé, 18-03-2012:5)

Bike rider gives Senator's wife something and Senator gets angry

From the two headlines there is the lexical 'nńkan' which literarily means a thing or something. However, from the context in which it is used we can ascribe another meaning to it. In headline (1), nnkan could possibly mean 'an item ' peculiar to òyìnbó (a white person ). The next question is what is the item? The news story that follows headline 1 is all about Chief Alex Akinyẹlé , a former Nigeria's Minister of Information whose first wife was a Briton(òyìnbó). After the death of the wife , Alex Akinyẹlé re -married to another Briton (òyìnbó). His penchant for marrying foreigner, British nationals in this instance, is what the newspaper is conveying to the reader. The writer then uses nnkan possibly to refer to (a) care being given by white women to Akinyẹlé , (b) food and delicacies that are typical of the white people, (c) the private part of a white woman or (d) a cumulative of sexual and romantic dexterity that a 'white' woman is known for.

In headline 2, nnkan that was given to Senator 's wife belongs to the bike rider (olọkadà). The news story tells about a Senator's wife who was having extra marital affairs with a bike rider. She was lured into this affair because, the husband, a Senator of Federal Republic of Nigeria was too busy with his oversight function in the National Assembly, leaving the wife's emotional needs unattended. To fill this vacuum, the wife found solace in a young bike rider. The 
headline writer therefore uses nnkan to mean sexual intercourse, whereas the lexical has the potential of having other meanings which include an object or an item.

One of the building blocks of language comprehension of Yorùbá newspapers is the ability of the reader to access the meaning of words as they are encountered, and to develop an interpretation that is consistent with the context. This process becomes particularly interesting at a choice point in understanding, as is the case with lexically ambiguous words. When a word has multiple meanings, one meaning must be selected while somehow retaining the possibility of using the alternative meaning. Additionally, the working memory capacity of individual readers affects their ability to maintain various representations in the process of understanding a sentence. The use of nnkan in headlines (1) and (2) creates ambiguity for the reader who is left with two options. Either to read the entire news story in order to resolve the ambiguity or skip over the headlines without resolving the ambiguity. The Yorùbá newspaper writer uses lexical ambiguity as seen in the above examples, to attract, sustain reader's attention and possibly force the reader into reading the story in order to resolve the ambiguity.

Another lexical item that is frequently used in contemporary Yorùbá newspapers which creates ambiguity is kinni (something). The Yorùbá newspaper writer is aware of the reader's culture; one that frowns at the use of lewd words and profane language. Therefore, the writer uses words and expression that are gentler or less direct than the one normally used to refer to something unpleasant to the ears or embarrassing. Because the writer is conscious of the Yorùbá morality and associated ideals, and he needs to make references to objects, things, sexual relations and human sex organs, he devices some words to convey his intention. Let's examine the following headlines.

(3) Șeun kọ Káyọdé sílẹ, ó ní ó fi ìà kinní jẹ òun (Akéde Odùduwà, 03-03-2008:14) thing

Seun divorces Kayode, she claims she is deprived of the

(4) Ééwo mú mi lójú kinni (Akéde Àgbáyé, 12-06-2001 :8)

I have boil on my thing

(5) N'Íbàdàn, bàbá gbé kinní si kinní mi (Aláròyé, 14-08-2001: 8)

In Ibadan, old man puts something into my thing.

In each of the headlines above, kinni (something/thing) is used to denote both man and woman's genitals. kinni is euphemism for penis in (3), virginal in (4) and both penis and virginal in (5). The word is employed to avoid being vulgar, thus defamiliarizing a familiar thing by glossing over the right Yorùbá words okó for penis and òbò for virginal. Apart from avoiding vulgar language, the writer uses the ambiguous word kinni to sustain readers' attention because readers' eyes would remain longer on an ambiguous word than a word that has no such ambiguity effect. Interestingly, this type of ambiguous word increases reading time - the process that makes the headlines become more memorable.

Pẹlú is another word contrived by Yorùbá newspaper writers to create ambiguity in the headlines. When used, it has capability of generating more than one meaning. For example:

(6) Sir Shina Àkànni gbé orin aládùn ẹ lọ sí Canada pẹ̀lú London

$$
\text { (Akéde Odùduwà, 03-03-2008:11) }
$$

Sir Shinna Akana takes his music show to Canada with (and) London

This is also ambiguous because we can ascribe two meanings to it. (a) Shina Akanni took his musical show to Canada and London (b) Shina Akanni took his musical show to Canada with or alongside London (denoting that someone whose name is London accompanied him). The ambiguity in the above headline results from the use of pẹlu (with) instead of the coordinating conjunction àti (and).

\section{Structural Ambiguity}

An expression is deemed ambiguous if it has more than one interpretation or meaning. That is, a state of an expression having two possible interpretations from an expression. Ndimele (1999) sees ambiguity as a grammatical phenomenon in which an expression can be given more than one interpretation. He likens ambiguity to polysemy in the sense that one stretch of utterance is given more than one meaning. This is what Hirst (1987) calls structural ambiguity. Structural ambiguity includes ambiguities caused by syntactic structures that lend themselves to more than one interpretation, such as phenomena of ambiguous word order, referential ambiguity, and prepositional phrase attachment.

While trying to be compact, precise and attract the reader, the Yorùbá newspaper writer ends up composing ambiguous headlines. This is sometimes due to influence of the headline code of English. In the following example, what the writer most likely wants to express is Governor of Zamfara 1.

(7) Gómìnà Zamfara fún kíloọọù Gusau ní míliọnù mẹtàlá náírà

(Akéde Àgbáyé , 20-12-2001:12)

Zamfara Governor donates N13 million to Gussau club

The headline above has two meanings. (a) A governor, whose name is Zamfara, donates 13 milion naira to Gusau football club. (b) Governor of Zamfara donates 23 milion naira to Gusau football club. While the noun phrase Góminà Zamfara, is poetic and orally lighter, the confusion it creates takes away from the message and prevents easy understanding which is one of the objectives of Yorùbá newspapers. To resolve the ambiguity, the writer needs to modify Zamfara with 'ipinlẹ (State), therefore the headline should read:

Gómìnà ìpínlẹ Zamfara fún

kílọọ́bù Gusau ní

míliọnù mẹtàlá náírà

Zamfara State Governor donates N13 million to Gussau

1 One of the 36 States in the Federal Republic of Nigeria 
Club

Another example:

(8) İyàwó ilé fẹ́ kọ ọkọ nítorí kò bộwọ̆ fún àwọn òbí ẹ̀. (Aláriyá Odù duwà, 05-03-2012:11)

House wife seeks divorce because he does not respect his parents

While the first part of the headline is not ambiguous, the second part exhibits ambiguity and is capable of having two meanings. The possible meanings are: (a) Wife seeks divorce because he does not have respects for his parents (b) Wife seeks divorce because he does not have respect for her parents.

If the headline had read:

'İyàwó ilé fẹ́ ko ọko nitorí kò bọwọ fún àwọn òbí òun',

House wife seeks divorce because he does not respect her parents

the ambiguity would have been prevented. However the newspaper writer chooses the headline to persuade the reader into reading in order to know who is being disrespectful between the husband and wife. It was after reading the news story that I understood it is the husband that is being rude to his in-laws. Creating ambiguity in the headline is deliberate and aimed at forcing reader to read the news story.

We can compare the above to the following headline on the same page of the newspaper:

(9) Bùkọ́lá fẹ́ kí ilé ẹjộ tú ìgbeyàwó òun ká

ó ní ọkọ òun kì í tọjú òun pệlú àwọn ọmọ (Aláriyá

Oòduà, 05-03-2012:11)

Bukola wants court to dissolve her marriage

She says her husband does not take care of her

The use of first person pronoun òun in the above example as against ẹ in the first example prevents ambiguity. The writer demystifies the ambiguity in this example in order to achieve effective dissemination of message without creating any aesthetic difficulty for the reader.

The following headlines are also structurally ambiguous:

(10) Àwọn owó burúkú tí Bàbángídá kó jẹ lộdún

1991

(Aláròyé, 25-05-2010:1)

The funds that Babangida loots in 1991

Owó burúkù (literarily means bad money) but what the writer intends to convey is 'lots of money'. The writer deliberately uses owó burúkú (bad money) because it has become a slang among the Yorùbá to use the phrase to describe a very rich person, hence we hear expressions such as; owó burúkú wà lớwọ ẹ (he has lots of money ). Beyond this, however, the writer and indeed the Yorùbá people use owó burúkú to describe someone's monetary riches when the source is questionable. This is a case of deliberate ambiguity in that the writer wants to manipulate reader's perception of the referent, Babangida, as a looter of public treasury hence he qualifies his money with burúkú

Other examples of structural ambiguity are:

(11) Egbẹ́ awakọ̀ kọlu ara wọn ní ilú İjẹ̣bú Òde (Àjọòo, 8-14 Nov, 2004. p. 14)

Drivers union fight each other in Ijebu-ode

The headline could be ascribed two meanings. (a) Members of same drivers' union fight one another

(b) Two different drivers' union fight each other

Again the newspaper writer deliberately creates ambiguity in the headline possibly because he is not sure of the identity of drivers union. There are two Drivers' unions is Nigeria, National Union Road Transport Workers and Road Transport Employees Association. The writer is aware of these drivers' unions but deliberately kept silent on the identity of the union perhaps so as not to be seen as taking sides or he was not sure whether it was members of the same Union that were fighting or the two rival unions that were armed against each other.

The next example of structural ambiguity in headlines of Yorùbá newspapers is worth examining because the ambiguity is wrapped in a figure of speech - personification.

(12) İgò ọtí pa bàbá ìyàwó lọ̣ jộ ikómọ (Äjọrò, 8-14 Nov, 2004:14) ceremony.

Beer bottle kills father-in-law during naming

Here are the possible meanings the headline could have:

(a) Father-in-law was killed by a bottle of beer, (b) father-in-law was intoxicated by a bottle of beer he drank, (c) father-in-law died from injury inflicted on him with a bottle of beer.

In the above example, the newspaper writer wants reader to know what actually caused the death of a father-in-law at the naming ceremony of his grandchild. In his attempt to portray this he ascribes human attribute to the beer bottle as if the bottle had hand to take action by itself. It is only by reading the accompanying news story that the reader could realise that it was an individual who was fighting another man that mistakenly stabbed the father-in-law to death while the deceased was trying to separate those who were fighting. While the writer is able to keep reader in suspense and seduce him to read on, he creates ambiguity and leaves the reader wondering about the possibility of a bottle being able to kill a person. The ambiguity would have been resolved if the headline had read:

Wọn fi igò ọtí pa bàbá ìyàwó lọjọ ikómo

Father-in-law stabbed to death with beer bottle at naming ceremony

\section{Conclusion}

As earlier mentioned, the 100 headlines in the corpus were subdivided into two categories: lexical and structural ambiguity. On a total of 100 headlines, the majority (66\%) was found to be ambiguity at lexical level, while the rest (34\%) presented some sort of structural ambiguity as shown bellow.

\begin{tabular}{|c|c|c|}
\hline No. of Headlines & Lexical Ambiguity & Structural Ambiguity \\
\hline 100 & $66 \%$ & $34 \%$ \\
\hline
\end{tabular}

Presumably, most headlines in the corpus are examples of lexical ambiguity which create involuntary humour and give 
the readers some sort of verbal pleasure. The lexical items such as 'kinni', nnkkan' and pẹlú change meaning in their different interpretations. The frequency of lexical ambiguity seems to be higher and is deliberately contrived by Yorùbá newspaper writers to achieve effective communication and aesthetics.

\section{REFERENCES}

[1] Bell, A. (1991). The Language of News Media. Oxford and Cambridge, MA: Blackwell.

[2] Chomsky, N. (1965). Aspects of the Theory of Syntax. Cambridge: M. 1. T. Press.

[3] Clifton, C. Jr., \& Ferreira, F. (1989). "Ambiguity in Context." Language and Cognitive Processes, 12, 77-103.

[4] Dor, D. (2003). "On Newspaper Headlines as Relevance Optimizers." Journal of Pragmatics 35(5), 695-721.

[5] Fairclough, N (1989). Language and Power. Harlow: Longman.

[6] Finegan, E. \& Besner, N. (1989). Language: Its structure and use. New York: HBJ.
[7] Fowler, R. (1991). Language in the News: Discourse and Ideology in the British Press. London and New York: Routledge.

[8] Franz, A. (1996). Automatic Ambiguity Resolution in Natural Language Processing. An Empirical Approach. Berlin: Springer.

[9] Gernsbache,r M.A. (1990). Language comprehension as structure building. New Jersey: Erlabaum.

[10] Giora, R. (2003). On our Mind. Salience, Context, and Figurative Language. Oxford: Oxford University Press.

[11] İșọlá, A. (1998). The Modern Yoruba Novel: An Analysis of Writer's Art. Ibadan: Heinemann

[12] Leech, G. (1969). A Linguistic guide to English Poetry. London: Longman

[13] Olateju M.O.A (1998). Syntactic Approach to Literary Discourse Analysis: The Yoruba Example. Ibadan: Unpublished Ph.D Thesis, University of Ibadan.

[14] Oșunnúgà, O. (2001). Language Style of The Yoruba Newspapers: Alaroye as A case Study. Unpublished M.A Dissertation, University of Ibadan

[15] Reah, D. (1998). The Language of Newspapers. London and New York: Routledge. 